\title{
Local Elections as a Sphere for Forming Citizens' Political Identity
}

\author{
AGNIESZKA TURSKA-KAWA AND MIRO HAČEK
}

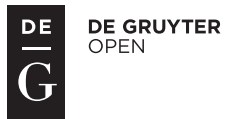

Politics in Central Europe (ISSN: 1801-3422)

Vol. 13, No. 2/3

DOI: 10.1515/pce-2017-0003

\begin{abstract}
The specificity of local elections supports the idea that there is significantly more chance of developing political identity at the local level. Given the social specificity of local elections, we propose three hypotheses with the aim of ascertaining whether (i) the greater significance of these elections, (ii) the specificity of their political programmes and/or (iii) the proximity of voters to candidates lead to a stronger sense of individual political identity. These hypotheses are verified from a comparative perspective by reference to local elections in Poland and Slovenia.
\end{abstract}

Keywords: local elections; political identity; politics; Poland; Slovenia.

\section{Introduction}

The forming of an individual's political subjectivity in their local environment is linked to the development of their political identity. This identity concerns the parts of the individual's identity that display their political values and political beliefs as well as the categories of their political thinking. Forming this identity means searching for answers to personal questions such as "Who am I in this current socio-political reality?", "What political values are important to me?", "Am I part of the social environment?" and "If so, how?" It also means finding answers to socio-political questions like "Which political organisations/parties share my values/needs/motivations for taking action?", "Do these political organisations/parties represent the region's interests?", "If so, how do they do this?" and "Is this particular political organisation/party respected in the local context?" Additionally, a citizen's political identity takes shape in response to 
questions about their political position: the political values they prefer, their political identifications and beliefs and the categories of their political thinking. Political identity is almost always associated with a group affiliation, showing how membership of a particular group can convey specific political opinions and attitudes. In some conceptions, identity is perceived as a state; it is something that an individual or a group has which ensures their coherence and distinguishes them from others. More often, however, identity is understood as a process. This approach allows for and stresses the changeable nature of identity. This does not mean that identities are volatile or unstable. Rather, it is the basis for a dynamic reading that points to the possibility of filling identity with different meanings and symbols and negotiating its content through interactions with other people, groups or the socio-political context. Identity, thus, becomes an effect of choices and different impacts. At its core is the answer to the question "Who am I?", which determines an individual's constancy and the coherence of their behaviour across different situations.

The contemporary social environment is highly labile and diverse, producing often changing demands and contexts in which individuals operate. As well as highly dynamic change, key characteristics of the social context are the variety and variability of options; a focus on short-term temporality; the changing importance of individual and social resources; and the dominance of a prefigurative culture, detraditionalisation and individual identity ("me") over social identity ("we") (Appelt 2005: 541). Social expectations that are constantly being modified and hard to predict produce citizens with a highly individualised identity and a poor sense of group identity. The role of regional communities in these processes is also reflected in identity transformations. Key concerns include the fact that within community networks, location loses its importance and is often illusory (Giddens 1991). Moreover, the rapid pace of change affecting nearly all spheres of human life make it is difficult to find a sense of security in one's environment that would have lasting value and promise a specific future. We must therefore ask whether deliberating on political identity is even worthwhile at a time when the constancy of identity is being questioned and the difficulty of finding stable, crystallised identities has been highlighted at both the individual and group levels. In contemporary politics, it is becoming increasingly hard to find lasting sets of political ideas and values as well as stable entities that represent those ideas and values.

The specificity of local elections seems to support the idea that political identity is significantly more likely to emerge and develop at the local than the national election level, and this forms the main thesis of this article. Given the social specificity of local elections, we also propose three particular hypotheses. The first holds that the greater significance of local elections generates a stronger sense of individual political identity. The significance of these elections is linked, for example, to their social importance and the motivations for taking part in 
them as well as other incentives. In both Poland and Slovenia, local elections are often described as second-order elections, however these contests have recently become more important as the regularity of certain political processes and anti-political statements points to their role in forming voters' political identities. The second hypothesis states that the use of concrete political programmes leads to a more robust sense of individual political identity. Political messages based on hard-to-grasp values with which citizens only identify momentarily will only motivate them incidentally. In contrast, messages that raise issues that matter directly to voters, connect to their everyday lives and substantially explore their immediate social environment link the electorate more solidly to the political entity that will be responsible for representing their individual interests. The third hypothesis refers to voters' personal relationships with the politicians running in local elections and holds that the proximity of voters to a candidate generates a stronger sense of individual political identity. At the local level, politicians are on average more independent and less connected to political parties. The proximity and familiarity of candidates may activate a number of psychological mechanisms leading to the denial of content-based discourse.

We set out to verify these hypotheses from a comparative perspective by referring to local elections in both Poland and Slovenia. Poland and Slovenia joined the European Union at the same time in 2004 and have some similarity historically since both were part of the Austro-Hungarian Empire before the First World War, endured the trauma of the long period of communist rule and have been successful in the processes of democratic transition and consolidation. Of course, there are also substantial differences between the two countries, not least of which is the sheer difference in their size, both in terms of population and territory, and their distinct political systems and systems of local government. Nevertheless, Poland and Slovenia share some distinct features in the context of local politics, including the tendency of voters to distrust major political parties and their partiality for "non-political" candidates and lists.

\section{Political identity}

Identity encompasses an individual's beliefs, interests, needs, motives, values, way of thinking and criteria for making evaluations. At the core of identity is the answer to the question of who the person is. Within the community with which they identify, the individual also develops a sense of social identity, i.e. a "we"identity formed on the basis of their perceived and experienced similarities with other people. This has some consequences for their sense of community, which emerges through cognitive connections with other people and identifications with their goals, values and principles of conduct (Jarymowicz 2000: 117; Turner 2000: 18). In local elections, messages that invoke a person's regional identity are important, highlighting a specific type of social identity. That identity is 
also based on regional traditions, i.e. practices that refer to a clearly defined and delimited territory or region (location) and the specific social, cultural (symbolic), economic or even topographic properties that distinguish it from other regions (locations). ${ }^{1}$ Most often, a fully developed regional identity is associated with pro-social behaviours aimed at maintaining traditions and bonds with the residents of a given place. Where the relationship is strongly emotionally marked, the belief that identity is endangered may lead to aggression or terrorist action, as exemplified in the Balkan conflicts.

According to Henry (2001: 49), political identity originates in certain features in each individual that enable them to develop a group identity. These include the capacity to reflect on issues, to negotiate and to identify oneself as a member of a group with specific goals and preferences. Henry argues that we can define political identity by reference to several factors: (a) the whole system of relations between citizens and institutions, including the behaviours involved, the form of political participation, the criteria for resource-and-cost allocation and how these are actually implemented; (b) the values and (rational and irrational) symbols on which collective narratives and any latent consensus are built and the justifications for allocating risks, costs and benefits; and (c) a reflexive combination of components (a) and (b). Political identity is, thus, understood in terms of a shared way of acting and thinking among a group of citizens with regard to political institutions and their operation. Mouffe (1992) strongly emphasises ideological elements, arguing that political identity is the effect of community members' internalisation of a political system in the form of concepts, feelings and assessments. Obviously, all this requires an appropriate level of competence and political knowledge, which both above mentioned authors relate to rational action theory. In particular, they assume that citizens should take part and be interested in politics and make decisions after thoroughly thinking over the interests of political entities.

For Markiewicz (2014: 82), political identity can be categorised by way of three models: (a) hard political identity, which is seen among the followers of certain political ideologies; this is fundamentalist in nature and involves self-identification through fighting and confrontations with others about particular ideas and values; (b) programmed political identity, which is typical among certain active politicians; this is the result of a party programme and need not be reflected in the politician's self-definition since they are only (re)presenting the programme publicly; and (c) soft/blurred political identity, which is typical of most citizens; this describes the occasional identity of someone who takes an interest in politics from time to time, particularly when making political decisions in referenda or elections; citizens usually choose their political orientation based on emotions and others' opinions.

1 Defined in this way, regional identity is also a specific kind of cultural identity (Szczepański - Sliz 2010: 15-19). 


\section{The social specificity of local elections}

Elections at the local level have a number of distinct features from a social point of view. On many understandings, these elections are of secondary importance. Reif and Schmitt (1980: 6-11) argue, for example, that there are at least two distinct planes of electoral exploration. The first describes nationwide (presidential and parliamentary) elections, which have a higher status given their systemic and social significance. The second plane covers second-order elections, including local and European Parliament elections. We can detect two determinants of this situation: (1) voter apathy that may be due, for example, to the holding of an excessive number of elections in a short time; as a result, these contests may undercut one another's importance and cause electoral passivity and (2) growing political polarisation that may be caused bycampaign topics that are disconnected from the party mainstream or by the engagement in political games, e.g. attempt to focus on petty issues in order to weaken other candidates rather than pursuing real political action (Drachman - Langran 2008: 134).

As Reif and Schmitt (1980) point out, second-order elections are influenced by primary elections. After a primary election, voters may, for example, have the opportunity to demonstrate their dissatisfaction in a second-order election. As Reif and Schmitt emphasise, in second-order elections, voters vote with their hearts far more often than they do with their heads. The "heart" is, however, subject to various emotions and moods that may increase voter volatility and prevent the crystallising of political identities.

Local elections provide a weaker mechanism for strategic voting, which is more important in national elections. Citizens' motivations for allocating their votes are, thus, different in these two systems. Significantly, in local elections, it is more important to stress regional affiliations than party preferences. To understand how an individual develops attachments and identifications with a given place, we need to consider the two psychological processes that underpin this relationship and make it stable over time. The first of these is the need to belong, which relates to needing to belong and be accepted by a particular group. A rewarding sense of one's group affiliation is a significant element of the social bond; Turowski (1995: 22) describes this in terms of group awareness, collective awareness and a sense of connection or solidarity. The second process concerns social identity, and here location is one of the basic indices. Bretherton and Fogler (1999: 26) emphasise that identity results from membership of social groups or the sharing of sets of norms and values among a number of individuals.

The minimal scope for strategic voting in local elections opens up a space for concrete campaign topics. Local politics is a critical sphere since it is about decisions that directly affect a person's life in the place where they live. This means that there is more room for initiating conversion in local elections. If the community's interests are to inspire individuals to act politically, then they must 
become part of that person's subjective interests. Once the collective interest transforms into someone's subjective interest, they begin to attach more value to political action and the achievement of political goals tied to both subjective and collective interests. In an analysis of other studies, Skarżyńska (2002: 42-37) points out that the common interests of a community may become a subjective concern if the problem involves a small area (e.g. an immediate neighbourhood), is resolved in a specific time and is well defined. It is certainly easier for local authorities to apply this approach since their sphere of action reflects the immediate interests of individuals: their streets and playgrounds, their schools and parks. Topics raised at the national level are more general and distant from voters, and the effects of fulfilling electoral promises often only come years later. The problems raised in local campaigns tend to be significantly more concrete and closer to citizens' lives. What is more, this closeness means that voters have greater knowledge of these topics which they can then apply in their decision-making processes. If they identify with an issue, they can engage with the campaign by discussing matters with other residents, following election events and meeting with candidates. Based on the principle of reciprocity (Cialdini 2006), this engagement tends to lead to active participation in elections.

Being close to the issues can also help activate accountability mechanisms, which contribute substantially to electoral volatility. When the issues in elections are practical concerns that directly affect citizens' lives, voting can be tied clearly to the punishment or reward of particular entities, which is an integral element of retrospective voting. Because of the clear statement of specific promises during the campaign, it is significantly easier to assess the effectiveness of a candidate's actions as they are being carried out. The legitimacy of retrospective voting is often questioned on the basis that some skill is needed to assess an individual's situation at the micro-social level and the state of the national economy at the macro-social level. This theory assumes that citizens are able to assess the effects of authorities' actions retrospectively and then use that knowledge to decide how they will provide support (Turska-Kawa 2015: 238). This process appears to be far easier for voters at the local and regional levels. The issues are closer to their lives and more likely to be topical in the public domain, which will lead to some discussion about how election promises are being kept. When citizens make decisions without having deeper knowledge of a subject, they tend to base their reasoning on cognitive heuristics. This is a temporary source of support that is usually based solely on patterns that allow them to make a quick decision at little expense. ${ }^{2}$

2 There are three kinds of cognitive heuristics: availability (assuming that an event that comes readily to mind is highly probable), representativeness (comparing the situation to a typical scenario) and anchoring (applying opinions already heard from others to form one's views on a matter). 
At the local level, voters are significantly closer to candidates, which leads to special motivations in elections. Both willingness to vote and vote allocation may be effects of the frequency of contact; in other words, the more often we meet a person, the more likely it is that we will have sympathy for them. These effects have greater weight when candidates are from our own neighbourhood, local community or professional circle. Depending on the specific problem, the impact may be temporary or lead to the replacement of substantive discourse with psychological closeness. What supports these relationships occurring at the local level, however, is the fact that party candidates often run as independents or as representatives of local or regional entities in local elections. Indeed, given some of the arguments raised above - the lower level of politicisation of local elections and the minimal scope for strategic voting and special identity-based motives - non-party candidates stand a better chance in these elections. The result is that they diverge from the party mainstream and discuss problems that are close to residents' lives. In departing from ideological issues and replacing them with practical concerns that are specific to the local community, they are, thus, responding to the various determinants of voter behaviour at the local level.

\section{The case of Poland: greater significance and less politicisation}

The year 1989 saw a transition within Poland from the party-based nomination to the free election of state authorities, one of the most important transformations of the Polish political arena (Zieliński 1996: 32). In the era of the People's Republic of Poland (1952 -1989), voters did not have a real choice when it came to supporting candidates; they could only choose between those who had already been approved by communist authorities. The regaining of basic political liberties, especially freedom of political expression and the right to political association (Antoszewski 2006: 77), allowed for the emergence of entities that could foster stable political identities in citizens based on their values. In this section, we set out to verify this study's hypotheses for Polish local elections.

\section{Significance of local elections}

As has been pointed out, local elections are usually understood as less systemically and socially significant than national elections. In Poland, however, the classification of local elections as secondary is not so obvious given a growing body of work that shows that these elections are highly important. Research by Wojtasik (2010) has proven that the concept of second-order elections cannot be applied easily to Polish local elections. Reports by the Public Opinion Research Center (CBOS 124 2014) also emphasise that for the last few years, Poles have attached greater importance to local elections than to parliamentary or even presidential elections. In fact, as Marody (2010) argues, while most Poles 
remain proud of their nationality, the state is no longer their point of reference and (state) authorities' decisions no longer drive their behaviour. Instead, they focus their loyalty, sympathies and interests elsewhere. These individuals believe that events in their neighbourhoods are important. They do not care so much about who sits in parliament since this is insignificant in their daily lives. They are also not concerned about whether authorities are respectful though, of course, they would prefer them to be efficient. This is clearly reflected in election turnout figures since 1998 which show stable voter turnout with an upward trend at the local level (1998 - 45.4\%; 2002 - 44.2\%; 2006 - 46\%; $2010-47.3 \% ; 2014-47.2)$ alongside unstable voter turnout for presidential elections (1990 - 60.6\%; 1995 - 64.7\%; 2000 - 61.1\%; 2005 - 49.7\%; 2010 $54.9 \% ; 2015-48.9 \%)$ and very low voter turnout for European Parliament elections (2004 - 20.9\%; 2009 - 24.5\%; $2014-23.8 \%)$.

It is interesting here to note the characteristics of individuals who consider local elections more important than national or European Parliament elections. A study by Turska-Kawa (2010: 328-347) shows that these individuals exercise their active voting rights more often and use opportunities to participate in decision-making about important issues for the country; they are more often members of certain organisations and show higher levels of motivation-related variables such as dispositional optimism and a sense of self-efficacy. Turska-Kawa's research also considered the variable of "religious practices". In Poland, religious practices play a significant role in people's positive attitudes to voting (see, for example, Marzec 2010 and Turska-Kawa - Wojtasik 2014). A Public Opinion Research Center study (CBOS 124/2014) carried out just before the 2014 local elections confirmed that those who attended mass services and religious meetings were more likely to express an intention to participate in local elections. At the same time, Turska-Kawa (2010) points to an interesting correlation: in her study, the people who engaged in religious practices tended to have lower levels of motivational variables such as dispositional optimism and a sense of self-efficacy. As religious practices are a kind of social activity, we might assume that the individuals who pursue them would have greater motivational resources. Turska-Kawa's work, however, reveals the opposite tendency: presumably, then, religious practices provide external motivation for those who fail to find an internal source.

\section{Content of political messages}

As we have seen, campaign issues raised at the national level are more general and distant from voters and the effects of fulfilling election promises often only occur years later. A Public Opinion Research Center survey (CBOS 66/2017) showed that two-thirds (66\%) of Poles agreed that the actions of most political parties were unclear and it was hard to guess what they really wanted to achieve. Most respondents (64\%) did not believe that the parties did their best to help 
ordinary people. In contrast, problems raised in local campaigns are often significantly more concrete and closer to citizens' lives. Furthermore, this closeness means that voters know more about the issues and can apply this knowledge in a decision-making process that requires less political expertise than would be needed for abstract topics. If voters identify with an issue, they can take part in the campaign by discussing matters with other residents, following election events and meeting with candidates.

Local identity is a special issue in Poland. In particular, this identity reflects a choice made more or less consciously by individuals who wish to cultivate and maintain a bond with their locality and community. This, in turn, determines their way of life and a set of psychological attributes that affect their attitudes to everyday matters. Local political groups, thus, focus their activities on issues present in the life of each resident. Developing a sense of belonging is far easier at the local level since many aspects of that identification result from having been born and socialised in a particular area and community. Moreover, stressing local identity as a source of psychological wellbeing may be a panacea for the breakdown of opportunities for social belonging and the difficulties with social embeddedness which are effects of globalisation.

In Poland, bonds with a region are often developed by reference to national identity, as reflected, for instance, in declarations and demands for a desired level of autonomy. Regional identity is older than national identity, and the latter has often been associated with centralisation and the imposing of solutions that are harmful to individual regions but support the exercise of power in some distant capital. Two dimensions of national identity are usually analysed: its continuity and its distinctiveness (Bokszański 2005: 109-110). In Poland, local and regional organisations have applied three basic strategies in connecting their demands with national identity. The first, regional autonomy stresses these organisations' absolute identification with the region, as reflected in their efforts to ensure full regional autonomy. The Silesian Autonomy Movement (SAM) epitomises this approach. It is a non-partisan association that tries to combine tradition and modernity, calling for contemporary steps to regain the autonomy that Upper Silesia enjoyed before the war. This is, in fact, highlighted in the association's first legislative goal. SAM has proposed a number of amendments to the Polish Constitution that would establish the autonomy of the regions (i.e. as autonomous provinces with independent laws) through relevant legislation and so protect their cultural heritage. In contrast, the second strategy, national-regional binarism points out the sense in belonging to a nation and a regional community at the same time. The Kashubian-Pomeranian Association exemplifies this strategy. It is a socio-cultural organisation for Pomeranians and anyone else who identifies with the organisation's goals. These goals mainly involve promoting a popular initiative for the overall cultural, social and economic development of Pomerania and the cultivation and development of its 
cultural specificity. The third strategy, national dominance, sees local identity as an aspect of national identity and treats the development of regional culture as a service to the state. This is the approach taken by the Podhale Residents' Society. The latter is one of the oldest and biggest organisations serving both native highlanders and supporters of the region who want to foster what is broadly understood as the culture of the mountain regions while supporting their economic development and helping to protect their natural environment. In this case, however, caring for this region does not mean separatism from the state as a whole; instead, it is a means of developing the nation (Turska-Kawa 2013: 35-51).

\section{Depoliticisation of candidates}

The latest study of the Public Opinion Research Center (CBOS 66/2017) confirms a phenomenon that has been at work in Poland for many years: the very critical attitude of citizens to political parties. Furthermore, a comparison with similar studies carried out six and sixteen years ago shows that this trend is growing rather than declining. The vast majority of respondents (91\%) in the 2017 study believed that political parties were responsible for the conflicts and turmoil in the country. Nearly as many people (87\%) agreed that the parties were nothing but cliques of politicians whose only goal was to gain power. Four-fifths $(80 \%)$ of respondents believed that party members were mainly motivated by personal ambitions. These attitudes are reflected in the levels of trust in leading politicians. A May 2017 survey (CBOS 59/2017) revealed that the mean rates for Polish respondents' trust in politicians were not high. Instead, they fell within a narrow range of +1.09 to -1.70 , where the maximum value $(+5)$ meant complete trust and the minimum value $(-5)$ meant extreme distrust. Andrzej Duda was listed as the politician most trusted by Polish citizens while Minister of National Defence Antoni Macierewicz was the least trusted.

The consequences of this trend can be seen in a situation that is widespread in local elections in Poland: representatives of political parties run without a party affiliation, that is, as independents or the representatives of local entities. Indeed, as we have noted, this strategy improves their chances of election. Before the most recent local elections in 2014, nearly two-thirds of eligible voters stated that they would prefer to vote for candidates who were unrelated to any party in the municipal or commune council elections. The inclusion of a party endorsement in pre-election statements was only a significant factor for slightly over one-sixth of respondents (CBOS, 124/2014). These statements tend to depoliticise local elections. Furthermore, support for candidates unattached to any political entity has been increasing in each successive election (2006 $50 \% ; 2010-52 \% ; 2014-65 \%)$. This pattern is even clearer in the case of the election of commune heads and town mayors. Before the 2014 local elections, two-thirds (67\%) of eligible voters expressed a preference for independent 
candidates; this was an increase of almost twenty percentage points from the result in 2010 (48\%).

In higher-level (regional) contests, the preference for specific candidates is replaced by a focus on ideological positioning and the selection of candidates who represent the voter's most preferred party. In Poland, this trend is clear from the difference between the results of commune elections (usually won by independent candidates) and regional council elections in the provinces (where political party representatives tend to win) (Wojtasik 2013: 212-213). Where independent candidates dominate, this tends to reflect a focus in their programmes on voters' real interests and the popularity of these candidates in their local communities.

Citizens' critical position on political parties can also be seen in the drivers of voting decisions at the local level. In these elections, stressing a candidate's connection with the residential area is more important than any party references. In some of these places, local identities have been deeply embedded, having been institutionalised via movements and associations that connect local people permanently and not just during elections; in these cases, elections tend to reflect the stable support of voters for their representatives. The organisations in question create common goals and focus their members' attention on ideas and plans that are important to them because of their place of residence. When nominating candidates for elections, these groups often base their programmes on official lists of their current activities.

In places where a strong local identity has not yet been formed, elections are open to candidates who have more or less gained popularity based on their short-term achievements and rise to power through various roles and positions. Social support is more contingent and connected with current affairs coverage, the electoral campaign and candidates' ambitions. Voting behaviours are less the consequence of relatively stable values and needs, leading to volatility in terms of voter activity/passivity and voting preferences. In Poland, local identities are significantly less established in western regions of the country where returnees settled after the Second World War. In those areas, people tend to turn to political parties. In eastern regions, where residence can be traced back over generations, local identities are stronger and support for candidates from local movements and associations is significantly higher.

\section{The case of Slovenia: local elections and the rise of "anti- politics"}

Political parties first appeared in Slovenia in the second half of the 19th century and were mainly representative of two large (clerical and liberal) blocs and one minor (socialist) group. Such parties disappeared before the Second World War II and were even prohibited in the post-war period (Lukšič 2001: 37). There are only two identifiable periods in Slovenian history during which partisanship 
has flourished: the early 1920s and the early 1990s (Lukšič 1994: 23). At the same time, an anti-party trend has been noted as a recent phenomenon in contemporary democracies around the world (Bale and Roberts 2002: 1).

It was only in the late 1980s and early 1990s that political parties were revived in Slovenia with the democratisation of political life, culminating in the first post-war democratic elections in the spring of 1990. The era of modern partisanship, thus, began in the early nineties. The end of the 1980s saw the formation of new political parties; at the same time, the old socio-political organisations, which had until then enjoyed a guaranteed monopoly as the organisers and leaders of all political interests and activities, were transformed into new political parties (Krašovec 2000: 23). At first, parties were based on the protection of the interests of specific social groups (through parties of peasants, intellectuals, pensioners, craftsmen, workers and so on) and they only later expanded their profiles to become political parties as we know them today (Lukšič 2001: 38).

During the years when Slovenia was seeking its independence, the newly established parties were primarily a vehicle for mass protest against the former regime and a means of striving for a more sovereign status for Slovenia. As such, they lacked more precisely articulated programmes covering the most important spheres of life. The consequence of this was a low level of ideological distinctiveness since the newly established political parties, though exhibiting great ideological differences, shared a single goal in whose name they were prepared to put aside their differences for some time (Krašovec 2000: 24). The Slovenian Constitution expresses relatively strong resistance to party politics and only mentions political parties in a negative context (Lukšič 1994: 26). Article 42 states that membership of political parties is forbidden to professional members of the police and armed forces. The Constitution takes a consistently liberal and anti-partisan position, including one article that states that members of parliament are representatives of the nation and "not obliged to follow any directions". The drafters of the Constitution clearly realised that political parties existed and parliament would always be a partisan institution but they did not recognise the natural right of those parties to be included in the Constitution (Lukšič 1994: 27). Moreover, the apogee of Slovenians' distrust of parties is the corporatist body known as the National Council (Državni svet). This body was supposed to remain beyond the influence of any political parties with candidates to be chosen by associations, social organisations, unions, professional chambers and universities, that is, by non-partisan organisations. Even so, half of its members, or twenty-two representatives, are individuals with local interests who are elected to the National Council each term and their names appear on party lists. As such, we cannot say that this body's operations are absolutely non-partisan. Nevertheless, the National Council, like the President of the Republic, remains an entity warranting support and protection under 
the Constitution if the latter is to prevent the parties' complete domination of Slovenian politics (Lukšič 1994: 28).

Krašovec (2000:26) states that a common problem for Slovenian political parties is their lack of structural connections to society, as can be seen from the public's negative responses to them. Although the Slovenian public strongly supported the pluralisation of political parties back in the early 1990s and communicated this position in some way through the 1990 plebiscite, trust in these parties began to decline significantly soon after the establishment of the multi-party system. Since 1991, the level of trust has plummeted; in 1991, 12.1\% of voters had a high or moderate level of trust in political parties; in 1995, this description only applied to $4.5 \%$ of voters (Krašovec 2000: 26). If we compare these data with the most recent figures (SJM 2015), we see that the percentage of respondents who trust political parties has been in constant decline (slipping most recently to $2.7 \%$ ) while the share of those expressing total distrust in political parties $(68 \%)$ has been rising.

To some degree, distrust in political parties can be traced to the installation of parliamentary processes in Slovenia. After so many years of a single-party system, citizens are still not ready to accept parliamentary debates that publicly expose social controversies. Unfortunately, these controversies have not been interpreted in a spirit of democratic debate among dissenting opinions but as rows, and, hence, a view has emerged that parliament is an unnecessary institution while political parties are quarrelsome entities. It is this open display of differing interests, a situation otherwise typical in a developed parliamentary democracy, which has earned political parties a bad name. At the same time, political elites have also contributed their fair share to this situation, having insisted that any non-acceptance or dissent from their standpoints represents a personal assault and not part of the political debate. Indeed, the lack of trust in political parties can be seen as a consequence of the visibly egoistic and ideologically burdened activities of the political elites (Fink-Hafner 1997: 152).

In contrast, non-partisan candidates and lists have seen increased success, and in the following section, we outline this trend and the resulting demise of political parties in local politics. At the same time, we provide a more detailed analysis of the results of five subsequent local elections, with an emphasis on the (growing) success of non-partisan candidates and lists.

The rise of non-partisan players and the demise of political parties: local elections Of the major differences that exist between national (parliamentary) and local elections in Slovenia, the most crucial concern the candidacy options of non-partisan entities and lists and these candidates' actual chances of being elected. The electoral system that is used for parliamentary elections favours established political parties. From the empirical evidence collected for all seven parliamentary elections carried out so far, it is clear that non-partisan candidates and 
those on non-partisan lists have somewhere between zero and a slim chance of being elected. Since the country's attainment of independence in 1991, no non-partisan candidate has even come close to being elected to the National Assembly and, in addition, the number of these candidates has always been very small. Since 2008, there have, in fact, been no non-partisan candidates whatsoever (Haček et al. 2017: 201).

In contrast, the situation is quite different at the local level of government. In its mayoral elections, Slovenia applies a two-round absolute majority electoral system $^{3}$ while in municipal council elections, both one-round relative majority and proportional representation systems are used depending on the size of the municipality (Kukovič - Brezovšek 2016: 76). ${ }^{4}$

We will focus our analysis on mayoral elections for which candidates may be nominated by either (registered) political parties or groups of voters. Non-partisan candidates may only run with the support of a group of voters, and the minimum size of this group depends on the size of the municipality where the candidature is lodged. ${ }^{5}$ This allows non-partisans to realise their candidate eligibility in a relatively undemanding way. Empirical data concerning local elections since 1994 strongly confirm this view: non-partisan candidates have been convincing winners of the last three mayoral elections with at least one non-partisan candidate running for mayor in the majority of municipalities. The number of non-partisans elected to mayor has risen sharply since 1998. Since the local elections in that year, most municipalities have had a mayor who was not nominated by a political party. Forty-three non-partisan mayors were elected in the 1998 local elections (across 192 municipalities). The figure was fifty-nine in the 2002 local elections (across 193 municipalities), sixty-six in the 2006 local elections (across 210 municipalities), seventy in the 2010 local elections (across 210 municipalities) and 115 in the 2014 local elections (across 212 municipalities).

Non-partisan candidates and lists have only been slightly less successful in municipal council elections. Here we may observe a significant difference between small municipalities (which use a one-round relative majority electoral

3 A candidate is elected mayor if they receive the majority of the votes. If no candidate achieves this majority, a second-round election is held between the two candidates who won the most votes. If several candidates receive the same number of votes, the second-round election candidates are selected by lot. The two chosen candidates are listed on the ballot according to the number of votes they received in the first-round election. If they received the same number of votes, the ballot order is determined by lot.

4 If a municipal council has between seven and eleven (incl.) councillors, its members are chosen via a one-round relative majority voting system. If the council has twelve or more councillors, the members are chosen via a proportional representation electoral system involving the use of preferential voting (Local Elections Act, Article 9).

5 When a candidate for mayor is proposed by a group of voters, they need to obtain supporting signatures from at least $2 \%$ of all voters that participated at the last local election; there must be no fewer than fifteen and no more than 2,500 signatures (Local Elections Act, Article 106). 
system) and medium-sized and larger municipalities (where a proportional representation system with preferential voting is used). A non-partisan candidate or list may be proposed by a group of voters permanently residing in the relevant election district. This group must collect supporting signatures from at least $1 \%$ of all voters that participated at the last local election, provided that no fewer than fifteen and no more than 1,000 signatures are submitted (Local Elections Act, Articles 54 and 68). The results show that non-party candidates and lists are also an overwhelmingly important political force in municipal council elections. In the most recent local elections, non-party candidates and lists accounted for $29.2 \%$ of all votes cast while the most successful political party (the Slovenian Democratic Party) received $14.3 \%$ of votes. In fact, the success of non-partisan candidates and lists has been growing since the first local elections in $1994 .^{6}$

\section{Why are non-party candidates and lists successful?}

When revisiting the local elections held to date in Slovenia, the question that inevitably arises is why non-partisan candidates and lists are enjoying increased success. Drawing on ongoing debates and empirical research, we can suggest at least three reasons for the relative success of non-partisan candidates and lists at the local level. ${ }^{7}$

First, at the national level, non-partisan candidates have had literally no chance of being elected to parliament given the existing electoral system with its explicit stress on the role of political parties. As such, the only viable way for them to realise their passive suffrage has been to stand as candidates in local elections (Kukovič 2016: 214). Second, we can detect a strong tradition of non-partisanship in Slovenia; put otherwise, Slovenian political parties have always attracted some sort of distrust or criticism (Lukšič 1994), and given the deepening economic and political crisis over the last decade, this negative reactions have reached new heights. Third, local elections are a more suitable venue for non-partisans realising their candidacy rights due to the narrower scope of these contests. Moreover, in local elections, voters opt for candidates who come from the place where they themselves originated and live, and so party

6 Non-partisan candidates and lists accounted for $22 \%$ of votes in the 2010 local elections; in the 2006 local elections, non-partisans received $19.9 \%$ of all votes cast. In both these contests, the most successful political party was the Slovenian Democratic Party, which obtained $18.7 \%$ of votes in 2010 and $17.3 \%$ in 2006.

7 It should be emphasised that the growing success of non-partisan candidates and lists is not an exclusively Slovenian phenomenon that might be tied to the peculiarities of the Slovenian setting; rather, it is a pattern that has been exposed elsewhere by many authors in their analyses. Writing on Finnish, Swedish and Romanian local elections respectively, Ylönen (2007: 7), Worlund (2007) and Enache (2011) find that voters' support for non-partisan lists has increased several fold in recent decades. Here we should also stress that non-partisan lists have not yet become a major political force in any of these three countries. 
allegiances are not as important as they are at the national level. Non-partisan candidates' political programmes tend to be more locally-oriented: they are often narrower, more closely focused on the given locality and less ideological than the programmes put forward by political parties. It is also often the case that voters know candidates personally, especially in very small municipalities. Both the candidacy and election of someone not linked to a party can strengthen local residents' belief that they can actually exercise the right to self-government in their own municipality. In Slovenian local elections, it may, thus, be said that the only true and undisputed winners are the voters, who are showing over and over at the ballot box that they are dissatisfied with political parties and their management of municipalities.

\section{Conclusions}

In the current world, the rapid pace of life and demands for flexibility and mobility are virtually inescapable. In this context, "mobility" can be understood broadly in terms of a readiness to make changes (e.g. to one's way of life or place of residence). Flexibility is the ability to adapt to transitory and constantly changing conditions (Bauman 1998: 14). Change is, thus, one of the fundamental elements of contemporary human life. It requires adaptation and impedes the crystallising of stable identities.

Identity formation is based on a sense of individuality, that is, an understanding of what makes one person (or group) different from others. This identification may also refer back to the elements that remain constant in a dynamically changing reality. Space is not only a place of interaction or a backdrop to events but also an elementary component of identity. Affecting the ontological individuality of the person or community living in a specific area, identity finds legitimacy in the space of the community, with its landmarks and its significant references. This symbolic space strengthens the awareness of territorial belonging, which, in turn, provides the basis for the myths that formally and culturally integrate members of the community. Space is, thus, an integral element of local elections. This was the inspiration for our thesis that it is far easier to influence an individual's political identity in local than in national elections.

The aim of the article has been to verify the statement that local elections develop a person's political identity far more effectively than national elections do. We have also suggested three more specific hypotheses that underpin this study. The first hypothesis states that the greater significance of these elections leads individuals to develop a stronger sense of political identity. Research has shown that elections with greater systemic and social significance are significantly more likely to inspire voters and generate lasting interest and positive emotions (Drachman - Langran 2008; Reiff -Schmitt 1980). Interestingly, analyses from Poland suggest that voters are finding local elections increasingly significant so 
the Polish example does not follow the classic model. Furthermore, individuals to whom local elections matter more than other elections have specific resources that are important part of political identity and contribute significantly to democratisation. In Slovenia, voter turnout figures would suggest that the importance of elections is slowly diminishing. Nevertheless, as voter support mounts for so-called non-partisan candidates at the municipal level, the possibility of running for office with a realistic chance of election or at least casting a vote for a non-party candidate has hugely increased the significance of local elections and local politics for voters and voter identity. More and more local non-partisan candidates and non-partisan lists are gaining support and taking over political decision-making at the municipal level. Their success, as reflected in high rates of re-election, is influencing not just the political identities of the general voting pool but party politics at national level as voters channel their local-level experiences into expectations about the national sphere of authority.

Our second hypothesis states that the concrete nature of political programmes leads to the development of a stronger sense of individual political identity. Both the Polish and Slovenian examples show that election programme content at the local level is developed entirely differently to such content at the national level and the studies presented prove that voters actually expect this. Thus, we find that local-level messages make more and more concrete references to voters' immediate environments: the roads they use, their schools and playgrounds, etc. These issues are closer to people's lives and these messages help them engage in decision-making processes since they not only allow them to identify with the problem but also make them feel responsible for the solution. In both countries, local identity is being referred to more and more often in local elections, which is itself an ongoing sign of the human need to belong.

The third hypothesis concerns the relationship between voters and the politicians running for office and it holds that proximity between voters and candidates produces individuals with a stronger sense of political identity. In both Poland and Slovenia, there is growing criticism of political parties. This has created the space for a special bond between voters and "non-political" candidates, who bill themselves as the opposite of politicians (presented as people who do not care about ordinary citizens). Clearly, this is related to the fact that candidates usually come from voters' immediate environment; they are familiar and have the same problems, and thus, the same goals as voters. At the same time, these candidates lack any background in politics, which - given current trends - enhances their credibility. In Slovenia, empirical data about local elections since 1994 confirm that non-partisan candidates have been convincing winners of the last three mayoral elections with at least one non-partisan candidate running for mayor in the majority of municipalities. Furthermore, the number of non-partisans elected as mayor has been rising sharply since 1998. In Poland, research confirms that voters put significantly more trust in candidates 
unrelated to political parties; these tendencies are apparent in both municipal/ communal council and commune head/town mayor elections (CBOS 124/2014).

\section{References}

Antoszewski, Andrzej (2006): Wzorce rywalizacji na arenie wyborczej (Patterns of Competition in the Electoral Arena), in Antoszewski, Andrzej, ed., Systemy polityczne Europy Środkowej i Wschodniej, Perspektywa porównawcza. 77-108, Wydawnictwo Uniwersytetu Wrocławskiego. Appelt, Karolina (2005): Środkowy okres dorosłości. Jak rozpoznać ryzyko i jak pomagać? (Middle adulthood. How to recognize risk and how to help), in Brzezińska, Anna l., ed., Psychologiczne portrety cztowieka. Praktyczna psychologia rozwojowa. 469-502, Gdańskie Wydawnictwo Psychologiczne.

Bale, Tim - Roberts, Nigel S. (2002): Anti-party sentiment and electoral system change: A New Zealand case study. Commonwealth and Comparative Politics 40 (2): 1-20.

Bauman, Zygmunt (1998): Globalization. The human consequences, Columbia University Press.

Bretherton, Charlotte - Vogler, John (1999): The European Union as a Global Actor. Routledge.

Bokszański, Zbigniew (2005): Tożsamości zbiorowe (Collective Identities). Wydawnictwo Naukowe PWN.

Burdzik, Tomasz (2012): Przestrzeń jako składnik tożsamości w świecie globalizacji (Space as an ingredient of identity in the world of globalization). Kultura-Historia-Globalizacji 11: 13-27.

CBOS 124 (2014): Wybory samorządowe (Local Elections). Centrum Badania opinii Spotecznej, komunikat z badań, Warszawa.

CBOS 59 (2017): Zaufanie do polityków w maju (Trust in Politicians since May). Centrum Badania opinii Społecznej, Komunikat z badań, Warszawa

CBOS 66 (2017): Ogólny stosunek do partii politycznych (General Attitude to Political Parties). Centrum Badania Opinii Społecznej, Komunikat z badań, Warszawa

Cialdini, Robert (2006): Influence: The Psychology of Persuasion. Harper Business.

Drachman, Edward R. - Langran, Robert (2008): You Decide: Controversial Cases in American Politics. Rowman \& Littlefield.

Enache, Ion (2011): Independents in the local politics of post-communist Romania. Romanian Political Science Review 11 (1): 51-104.

Fink-Hafner, Danica (1997): Development of a party system, in Fink-Hafner, Danica - Robbins, John R., eds., Making a new nation: The formation of Slovenia. 135-155. Aldershot.

Giddens, Anthony (1991): Modernity and Self-identity: Self and Society in the Late Modern Age. Stanford University Press.

Haček, Miro - Brezovšek, Marjan - Kukovič, Simona (2017): Slovenian politics and the state. Rowman \& Littlefield. 
Henry, Barbara (2001): Political Identity as Myth?, in Cerutti, Furio - Rudolph, Enno, eds., A Soul for Europe: An Essay collection. 49-72, Peeters Publishers.

Jarymowicz, Maria (2000): Psychologia tożsamości (Psychology of Identity), in Strelau, Jan, ed., Psychologia. Podręcznik akademicki (Psychology. Academic textbook). 107-125, Gdańskie Wydawnictwo Psychologiczne.

Krašovec, Alenka (2000): Power in political parties (Moč v političnih strankah). Faculty of Social Sciences Publishing House.

Kukovič, Simona - Brezovšek, Marjan (2016): From Parliamentarisation towards Presidentialisation: Institutional Aspects of Local Political Leadership in Slovenia. World Political Science 12 (1): 69-85.

Kukovič, Simona (2016): The Distinctions of Local Political Leadership in Slovenia: The Mayoral Political Career, in Turska-Kawa, Agnieszka - Haček, Miro, eds., Democratisation Processes in Poland and Slovenia: Comparative Study. 203-219, Lex Localis.

Local Elections Act (Zakon o lokalnih volitvah), Official Gazette of Slovenia, no. 94, 2007.

Lud urabia sobie państwo, interview with professor Mirosława Marody. At http://wyborcza. pl/1,76842,8455054,Lud_urabia_sobie_panstwo.html?as=2startsz=x\#ixzz1AFJWY6RH" "Gazeta Wyborcza", (4 August 2017).

Lukšič, Igor. (1994): Nestrankarstvo na Slovenskem (Anti-partisanship in Slovenia), in Lukšič, Igor, ed., Parties and Partisanship (Stranke in strankarstvo). 23-32, Slovenian Political Science Association.

Lukšič, Igor (2001): Slovenian political system (Politični sistem Republike Slovenije). Znanstveno in publicistično središče Ljubljana.

Miller, William L. (1998): Irrelevant elections? The Quality of Local Democracy in Britain. Clarendon Press.

Mouffe, Chantal (1992): The Identity in Question. Citizenship and Political Identity 61: 28-32.

Markiewicz, Barbara A. (2014): Sfera publiczna a kwestia tożsamości politycznej. Filo-Sofija 24 (1) 77-89.

Marzec, Magdalena (2010): Uczestnictwo Polaków w praktykach religijnych i ich ocena roli Kościoła w życiu publicznym (Poles' Participation in Religious Practices vs. their Evaluation of the Role of the Church in Public Life). Political Preferences 1: 227-254.

Reif, Karlheinz - Schmitt, Herman (1980): Nine Second Order National Elections: A Conceptual Framework for the Analysis of European Election Results. European Journal of Political Research 8 (1): 3-44.

Research Slovenian Public Opinion (SPO), Centre for Public Opinion Research, Ljubljana, 2005. At http://www.adp.fdv.uni-lj.si/opisi/sjm052/opis-podatkov/ (16 August 2017).

Skarżyńska, Krystyna (2002): Aktywność i bierność polityczna (Political activity and passivity), in Skarżyńska, Krystyna, ed., Podstawy psychologii politycznej (Fundamentals of political psychology). 26-58, Zysk i S-ka.

Slovensko javno mnenje (SJM), Faculty of Social Sciences, Ljubljana, 2015. http://www.adp.fdv. uni-lj.si/opisi/sjm15/snemanje/ (16 August 2017). 
Szczepański, Marek - Śliz, Anna. (2010): Dylematy regionalnej tożsamości. Przypadek Górnego Śląska (Dilemmas of regional identity. A case study of Silesia). Nowe Zagtębie 12 (6): 17-20.

Tomaszewski, Krzysztof (2007): Regiony w procesie integracji europejskiej (Regions in the Process of European Integration). Wolters Kluwer Polska.

Toš, Niko (ed.). (1998): Values in transition II (Vrednote v prehodu II). Faculty of Social Sciences Publishing House.

Turner, John C. (2010): Towards a cognitive redefinition of the social group, in Tajfel, Henri, ed., Social identity and intergroup relations. 15-40, Cambridge University Press.

Turowski, Jan (1995): "Więź społeczna w grupie (Social bonds in a group), in Starosta, Pawel, ed., Zbiorowości terytorialne i więzi społeczne. Studia i szkice socjologiczne dedykowane prof. W. Piotrowskiemu w 70. rocznicę urodzin. 18-42, Wydawnictwo Ut.

Turska-Kawa, Agnieszka (2013): Tożsamość miejsca w strategiach polskich organizacji regionalnych (Local Identity in the Strategies of Polish Regional Organizations). Rocznik Nauk Spotecznych 1: 35-51.

Turska-Kawa, Agnieszka - Wojtasik, Waldemar (2014): Religiosity and electoral participation: the case of Poland. Studia Methodologica 38: 6-23.

Turska-Kawa, Agnieszka (2015): Determinanty chwiejności wyborczej (Determinants of electoral volatility). Wydawnitwo Uniwersytetu Śląskiego Katowice.

Wojtasik, Waldemar (2010): Drugorzędność wyborów samorządowych w teorii i badaniach empirycznych (Secondary Nature of Local Elections: Theory and Empirical Research), in Barański, Marek - Czyż, Anna - Kubas, Sebastian, eds., Rola samorządu terytorialnego w modernizacji Polski (The Role of Local Authorities in the Modernization of Poland). 253-269, Wydawnictwo Uniwersytetu Śląskiego Katowice.

Wojtasik, Waldemar (2013): Istotność wyborów i jej czynniki w świadomości społecznej (The Significance of Elections and Their Role in Social Awareness). Political Preferences 2: 205-226.

Wörlund, Ingemar. (2007): The changing local party system in Sweden. Martin Luther University. Ylönen, Jorma (2007): The local non-partisan political groups in Finland -framework for research. ECPR Summer School in Local Government Torino.

Zieliński, Eugeniusz (1996): Przekształcenia polityczno-ustrojowe w Polsce (Political and Systemic Transformations in Poland), in Zieliński, Eugeniusz, ed., Transformacja ustrojowa państw Europy Środkowej i Wschodniej (Political transformation of the states of Central and Eastern Europe). 21-42, Dom Wydawniczy Elipsa Warsawa.

Agnieszka Turska-Kawa works at University of Silesia in Katowice at the Department of Political Science and Journalism. E-mail:agnieszka.turska.kawa@gmail.com

Miro Haček works at University of Ljubljana at the Faculty of Social Sciences, Slovenia.E-mail: miro.hacek@fdv.uni-lj.si 